\title{
Alluvial Aquifer in
}

Northeastern Louisiana-

A Large Source of Water

GEOLOGICAL SURVEY WATER-SUPPLY PAPER 1619-V

Prepared in cooperation with the

Louisiana Department of Public Works and the Department of Conservation, Louisiana Geological Survey

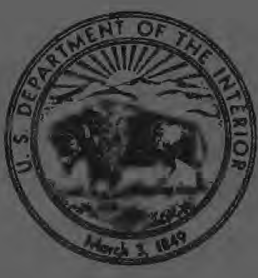




\section{Alluvial Aquifer in}

Northeastern LouisianaA Large Source of Water By A. N. TURCAN, JR., and R. R. MEYER

CONTRIBUTIONS TO THE HYDROLOGY OF THE UNITED STATES

GEOLOGICAL SURVEY WATER-SUPPLY PAPER 1619-V

Prepared in cooperation with the

Louisiana Department of Public Works

and the Department of Conservation,

Louisiana Geological Survey

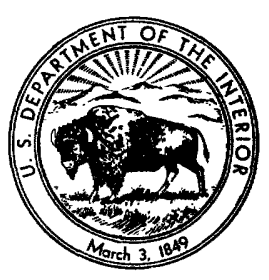




\section{UNITED STATES DEPARTMENT OF THE INTERIOR \\ STEWART L. UDALL, Secretary}

\section{GEOLOGICAL SURVEY}

Thomas B. Nolan, Director 


\section{CONTENTS}

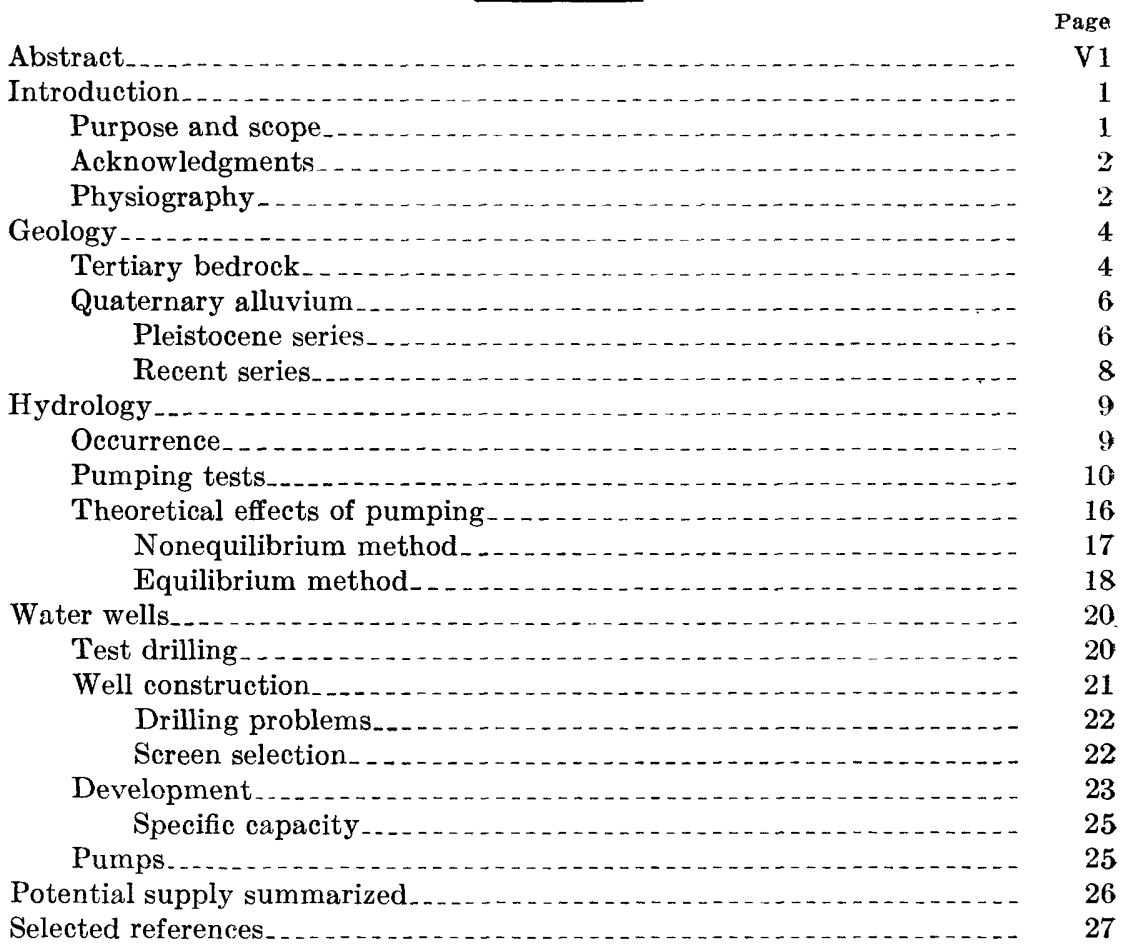




\section{ILLUSTRATIONS}

Figure 1. Isopach, structure, and location map of the Tallulah area...-

2. Geologic section of the Quaternary alluvial deposits.........

3. Hydrograph showing effect of barometric pressure changes on water level in well $\mathrm{Ma-12}$, May 1957 ....................

4. Hydrograph showing effect of barometric pressure changes on water level in well Ma-12, November-December 1956.....

5. Location and construction data of pumped and observation wells_.....

6. Logarithmic time-drawdown plot for well $\mathrm{Ma}-25-2$

7. Relation of apparent storage coefficient to time

8. Semilogarithmic time-drawdown plot of water levels in well

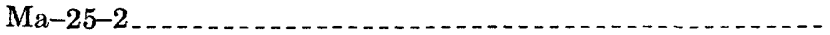

9. Semilogarithmic time-drawdown plot of water levels in well

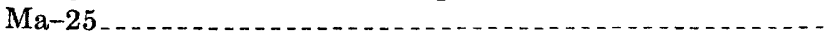

10. Semilogarithmic distance-drawdown relation for alluvial

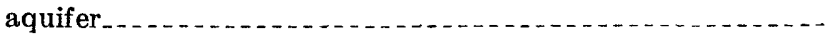

\section{TABLES}

TABLE 1. Measured operating yield and specific capacity of experimental irrigation wells in the Tallulah area

2. Specific capacity of irrigation wells in northeastern Louisiana and northwestern Mississippi._. 


\title{
CONTRIBUTIONS TO THE HYDROLOGY OF THE UNITED STATES
}

\section{ALLUVIAL AQUIFER IN NORTHEASTERN LOUISIANA- A LARGE SOURCE OF WATER}

\author{
By A. N. Turcan, JR., and R. R. Meyer
}

ABSTRACT

A properly constructed and developed well screened in the alluvial aquifer in the Mississippi River valley in northeastern Louisiana, especially in the vicinity of Tallulah in Madison Parish, would be capable of pumping as much as $7,000 \mathrm{gpm}$ (gallons per minute) without causing excessive water-level declines. To induce recharge from the Mississippi River, which also serves as a drain for the aquifer, large quantities (more than 100 million gallons per day) of water would have to be pumped from wells near the river.

To determine the optimum yield of wells and to provide a relatively economical source of irrigation waters in the Tallulah area, the Lovisiana Department of Public Works installed three experimental wells in the alluvial aquifer. During. the drilling, installation, and testing of these wells, hydrologic and geologic data on the aquifer were obtained. The permeability of the semiconfined alluvial aquifer is 1,700 gpd (gallons per day) per sq ft. Calculations were made using the nonequilibrium method of analysis and the data obtained in the early part of the test when water was released instantaneously from storage.

Observed pumping-test data and the equilibrium method of analysis were used to approximate the theoretical effect of pumping; that is, when the cone of depression reaches equilibrium in form, and drainage from the semiconfining material is relatively uniform.

\section{INTRODUCTION}

\section{PURPOSE AND SCOPE}

The agricultural growth in the Mississippi River alluvial valley of northeastern Louisiana, where Tallulah is located (fig. 1), depends largely upon the availability of water and an inexpensive means of water transmission. The Mississippi River and the alluvial deposits underlying the area are sources of large amounts of water for irrigation; however, the use of river water would require large pumping plants and a costly distribution system. Streams in the Tallulah area, such as Roundaway and Walnut Bayous, which bisect most of the agricultural land, are sources of irrigation water except during dry 
periods. These bayous and the large quantities of ground water in the interstream areas offer an economical solution to the problem of having irrigation water available when and where it is needed.

The Louisiana Department of Public Works made plans, based on sound hydrologic and engineering principles, for the proper recovery of ground water. In the spring and summer of 1956 , four test holes were drilled to locate favorable sites for wells along either Roundaway or Walnut Bayous. Three experimental wells were designed, installed, and developed on the basis of the quantity of water needed and the analysis of test-drilling data. The results were considered excellent in that the wells, whose yield was the highest on record in that part of the Mississippi River alluvial valley, provide an adequate quantity of water to supplement the flow of streams during the irrigation season.

As a part of the ground-water investigation being made in cooperation with the Louisiana Department of Public Works and the Louisiana Department of Conservation, data were collected and analyzed. This paper contains a brief discussion of physiographic and geologic conditions in the area; an analysis of data gathered during the drilling of the test holes and the testing of the experimental irrigation wells; a summary of well construction and development methods; and a summary of the analyses of data obtained during a pumping test made at one of the well sites.

\section{ACKNOWLEDGMENTS}

Most of the field data were gathered by personnel from the northeastern district of the Louisiana Department of Public Works under the supervision of S. C. Smith, District Engineer, and George Johns, Area Engineer. Acknowledgment also is given the Madison Parish Police Jury who permitted tests to be made on the experimental wells. Special thanks are given Mr. A. Kell on whose property observation wells were installed.

\section{PHYSIOGRAPHY}

The Tallulah area is in the Mississippi Alluvial Plain section of the Coastal Plain province (Fenneman, 1938, p. 65-99). The relief in the area is about 20 feet; the crest of the natural levee is at an altitude of about 90 feet and the lowest backswamp area at about 70 feet. The principal topographic features are natural levees and swamps.

The natural levees are restricted to the areas that border existing or abandoned stream channels. They are asymmetrical in profile; their crests border the stream, and their surfaces slope gently away from the river and merge into the backswamps. The maximum width of the natural levees adjacent to the Mississippi River is approximately 
2 miles, but the width of those adjacent to the small streams is about half a mile. Both the width and the height of the natural levees have adjusted to the flood heights of the parent streams. The altitude of the levees gradually decreases downstream; for example, the crest of the natural levee along Walnut and Roundaway Bayous declines about 5 feet in 35 miles.

The origin of the natural levees is ascribed to the decrease in velocity of the river water when it overflows the banks. The lower velocity causes deposition of load in decreasing amounts away from the stream until the landward slope of the levee reaches approximate equilibrium with the volume of water that overflows the crest of the levee.

In the Tallulah area, swamps generally are restricted to the interstream areas beyond the landward limit of the natural levees. The forested swamps are replete with concentric meander scars which are remains of the parent stream. Many of the scars contain shallow lakes, which are bordered by low ridges. The distribution of these lakes and ridges depicts the history of lateral cutting and deposition by former streams in the area.

The streams in the Tallulah area contrast greatly in amount of flow, depth, and other characteristics. The Mississippi River, which bounds the area on the east, is the largest river on the North American continent, whereas the Walnut-Roundaway Bayou system, which meanders through the heart of the area, contains little or no water during dry periods. The Mississippi River above Vicksburg, Miss., which is just a few miles downriver from the Tallulah area, drains an area of 1,144,500 square miles. The maximum flow is estimated to be $2,278,000 \mathrm{cfs}$ (cubic feet per second) and the minimum flow is 91,800 cfs (U.S. Army Corps of Engineers, 1950). The average channel width is about 2,500 feet, but where the course of the river has been altered by artificial means, the channel is narrower; for example, the width of the channel at the Marshall cutoff is approximately 1,600 feet. Although the Tallulah area is about 450 river miles upstream from the mouth of the Mississippi River, the river has scoured its channel to as much as 50 feet below sea level on the outside of meanders (U.S. Army Corps of Engineers, 1950, sheet 73). Between meanders the maximum depth of the channel is about at sea level.

The principal streams west of the Mississippi River are Walnut and Roundaway Bayous. Walnut Bayou begins near the artificial levee bordering the Mississippi River northwest of Tallulah and follows a meandering course for about 10 miles roughly parallel to the Mississippi River, whence it reverses direction and flows northwestward through Tallulah and enters Roundaway Bayou. Roundaway Bayou 
flows southeastward out of the area and eventually enters the Tensas River. The natural levees bounding the Walnut-Roundaway Bayou system have long been areas of habitation, as shown by the numerous Indian mounds. Today the natural levees form the principal agricultural land of the area. The importance of these landforms to the economy of the area is indicated also by the division of the townships into sections. South of Tallulah, the sections have not been surveyed into the normal plots of 1 square mile but rather into narrow strips, normal to the stream, that have a minimum width of about 500 feet and a maximum length of about $1 \frac{1}{2}$ miles. Division of the land into narrow sections is probably the result of the desirability of the high area of the natural levee bordering the streams.

Artificial levees have been constructed to a height of about 25 feet adjacent to the west bank of the river. Gradual shifting of the river channel has breached the old levees in some places, and new levees have been constructed more distant from the river.

The natural levees of the Walnut-Roundaway Bayou system perform an important hydrologic function in that most of the water from precipitation flows down the slope of the levees toward the backswamps and not toward the bayous. Only a few short tributaries and some drainage ditches enter the streams; consequently, the flow of the bayous depends chiefly on water from precipitation on the relatively narrow strip between natural-levee crests. If the flow of the Walnut-Roundaway Bayou system was adequate, it would form an ideal source of irrigation water, as the natural levees slope gently away from the bayous, and the course of the bayous bisects most of the potential irrigable land.

\section{GEOLOGY}

Viewed broadly, the general geology of the Tallulah area is very simple. The Tertiary bedrock in the area is considered to be of Eocene or Oligocene age. The bedrock is overlain unconformably by Quaternary alluvium deposited by the Mississippi River and its distributaries.

\section{TERTIARY BEDROCK}

The Tertiary bedrock immediately underlying the alluvium is composed principally of clay of the Jackson group of Eocene age and of the Vicksburg group of Oligocene age. South of the Tallulah area, where their full thickness is represented on electrical logs, the two groups are composed chiefly of clay and, consequently, are difficult to distinguish on the basis of rock type. The full thickness of the Vicksburg and Jackson groups, as shown by electrical logs, is about 550 feet. The groups have been beveled by erosion in the Tallulah area, and 1 mile north of Tallulah their thickness is only 150 feet. 


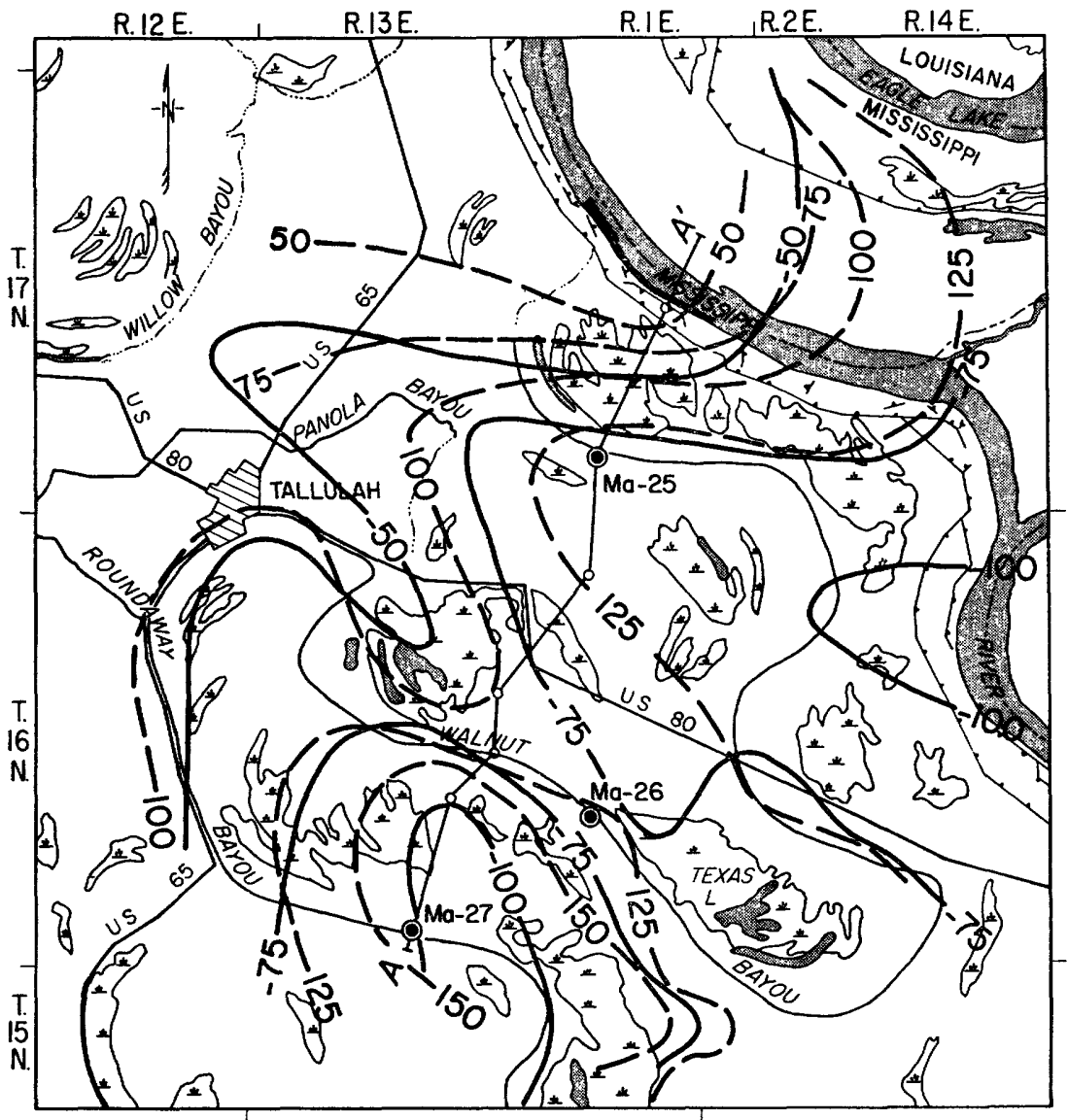

Map source: Army Map Service.

Talla Bena Quadrangle, 1939

\section{EXPLANATION}

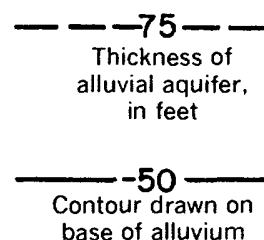

Contour interval, 25 feet

Revetment Datum is mean sea level
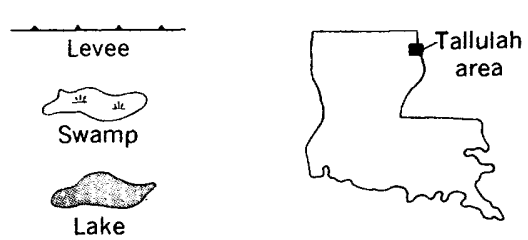

O

Experimental irrigation well

Control point

$1 \quad 0 \quad 11 \quad 2 \quad 3 \quad 4$ MILES

Figdre 1.-Location map of the Tallulah area showing physiographic features; location of experimental irrigation wells; the base of the alluvium and the thickness of aquifer, by contours; and location of generalized section $A-A^{\prime}$. (See fig. 2.)

$643873-62-2$ 
The irregularities in the eroded surface beneath the Quaternary alluvium are illustrated in figures 1 and 2.

Although electrical logs of oil test wells indicate that deep sands underlying the Jackson and Vicksburg groups in the eastern part of the Tallulah area may contain relatively fresh water, the principal hydrologic significance of the Tertiary bedrock is its function as an effective confining bed below the principal aquifer of the area.

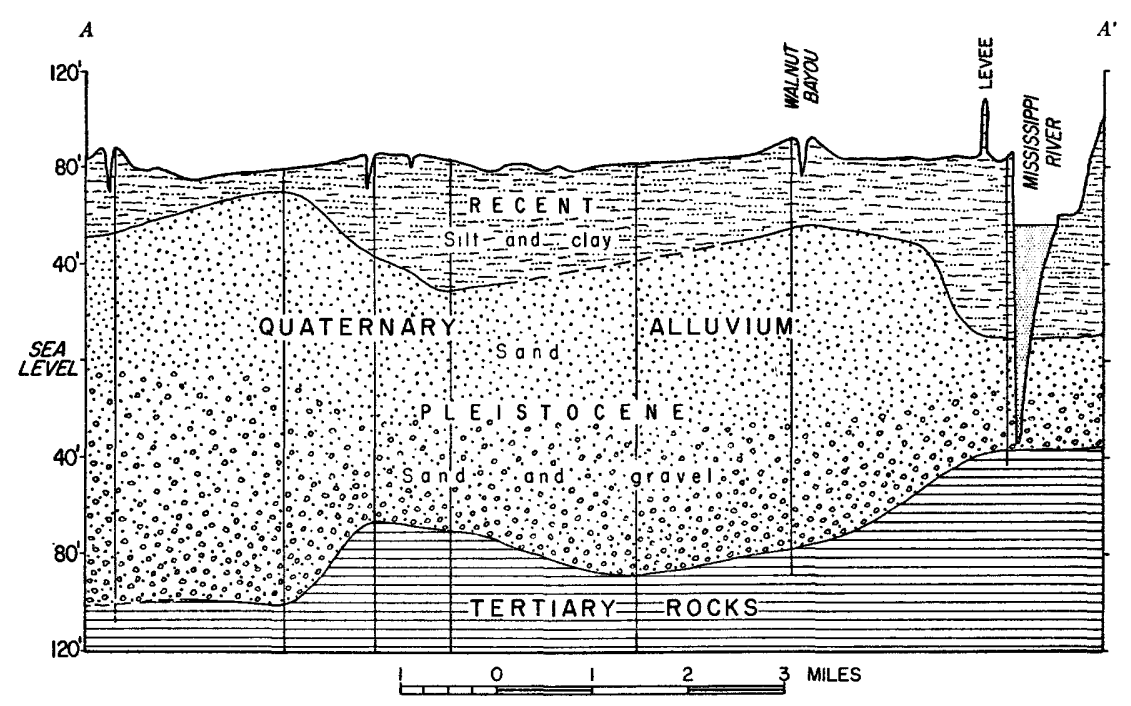

Figure 2.-Generalized geologic section of the Quaternary alluvial deposits near Tallulah.

\section{QUATERNARY ALLUVIUM}

\section{PLEISTOCENE SERIES}

The Quaternary alluvium is composed of two distinct but graditional rock types-the basal sand and gravel and the overlying silt and clay. The sand and gravel overlying Tertiary rocks in the principal stream valleys of Louisiana has been interpreted as Pleistocene in age by some geologists and as Recent by others. J. L. Poole (1961) gives reference to and a brief history of the various interpretations and concludes that in East Carroll Parish the sand and gravel phase of the alluvium is Pleistocene in age and the overlying silt and clay is Recent. East Carroll Parish is adjacent to the northern boundary of the Tallulah area, and the sand and gravel can be correlated easily from one area to the other. In addition to the evidence given by Poole, carbon-14 determinations show the age of the sand in the upper part of the alluvium in West Baton Rouge Parish to be about 21,000 years (U.S. Army Corps of Engineers, 1950). Thus the age inter- 
pretation in this report conforms to that used by Poole; namely, in the Tallulah area the alluvial sand and gravel is considered Pleistocene, and the overlying silt and clay is Recent.

One of the most distinctive features of the Pleistocene deposits is the upward gradation in grain size from the large gravel near the base of the deposits to the very fine sand underlying the silt. The material near the base of the deposit ranges in grain size from very coarse sand to small boulders. One small limestone boulder having a maximum dimension of $101 / 2$ inches was brought to the surface by drilling along the upper reaches of Walnut Bayou. The material overlying the sand and gravel grades in grain size from coarse sand to very fine sand at the top of the unit. The upper fine-grained sand merges into the silt of the overlying natural levee and backswamp deposits.

In Louisiana, the alluvial sand and gravel extends along the Mississippi River valley from the Arkansas State line southward, where it merges with marine sediments near the Gulf of Mexico. At the latitude of Tallulah, the sand and gravel was deposited on the eroded surface of the Tertiary bedrock from the highlands east of the Mississippi River to the bluff forming the west bank of the Ouachita River.

Although the base of the Pleistocene deposits is easily defined because of the change in material from sand and gravel to clay, the upper contact is difficult to determine precisely because of the upward gradation in grain size from very fine sand to silt. Because of this illdefined upper contact, the aquifer thickness reported in drillers' logs for a group of wells that have been drilled in one area may differ considerably. For example, the reported aquifer thickness at Tallulah ranges from 40 to 118 feet. Although there may be some difference in the thickness of the deposits within a small area, the wide range in reported thickness is probably due to differences in drilling techniques and interpretation of the upper contact of the Pleistocene deposits. The contours on figure 1 showing the aquifer thickness are based on the data that are interpreted as being the most nearly correct.

The Pleistocene sand and gravel lies unconformably on the eroded surface of the Tertiary rocks (fig. 2). The contours in figure 1 show the surface of the Tertiary rocks in the area to range from about 50 feet to slightly more than 100 feet below sea level. The surface, which is irregular and shows the effect of scour by the ancestral Mississippi River, has a general southward dip. During the Pleistocene epoch, the deepest scours in the Tertiary surface were filled with sand and gravel. Therefore, as shown in figure 2, the thickness of the sand and gravel is affected principally by the depth of the Tertiary rocks. The thickness ranges from about 50 feet in the northern part of the area to 170 feet in the southern part. (See fig. 2.) 
The sand and gravel is the most productive aquifer in the entire Mississippi River valley, and in the Tallulah area it is the only developed source of ground water. The great potential yield from this aquifer results not only from the high permeability of the sand and gravel but also from the large amount of water available from recharge or potential recharge. The channel of the Mississippi River incises the aquifer from south of Baton Rouge northward to beyond the State line, and the river is hydraulically connected with the aquifer. Therefore, if ground-water levels are lowered by pumping, water from the river would be induced to flow into the aquifer and would greatly increase recharge to the aquifer.

\section{RECENT SERIES}

The silt and clay overlying the sand and gravel of Pleistocene age correlates with the material in East Carroll Parish described as Recent in age by Poole (1961). Silt and clay deposited during periodic floods of the Mississippi River formed the natural levees and gradually filled the backswamps. Recent deposits range in thickness from about 10 to 90 feet in most of the area. Near Lake Providence, about 30 miles north of Tallulah, silt and clay of Recent age has been deposited in a cutoff meander loop of the Mississippi River, forming an oxbow lake. In places the channel of this abandoned meander had been scoured deeply, and only a thin bed of Pleistocene sand and gravel underlies the silt and clay. Fisk (1944, p. 19) referred to these clay- and silt-filled abandoned channels as "clay plugs." $\mathrm{He}$ includes within the same term arcuate "lows" or swales that have been filled with silt and sandy clay. Logs of wells indicate no deeply filled clay plugs in the Tallulah area. Many of the minor irregularities in thickness of the Recent deposits may reflect the filling of relatively shallow, low areas by silt during floods.

The silt and clay control to a large extent the occurrence of ground water in the area. These Recent deposits have not been compacted by overburden and consequently are relatively permeable. Thus some of the water from local precipitation is transmitted directly downward to the underlying sand and gravel. This recharge normally maintains the water levels above that in the Mississippi River, and consequently the river functions as a drain of the aquifer. In areas underlain principally by clay, such as the upper reaches of Walnut Bayou, the smaller streams are not connected hydraulically with the aquifer. The permeability of the Recent silt is much less than that of the underlying sand and gravel. Therefore, where the water level in wells is above the aquifer, the silt functions as a semiconfining layer when the well is pumped. If the well is pumped continuously and the 
water level in the vicinity declines below the silt zone, the confining effect gradually diminishes as the water drains slowly from the silt.

\section{HYDROLOGY}

\section{OCCURRENCE}

As discussed in the section "Geology," the sand and gravel phase, which is considered to be the aquifer, is overlain by silt and clay (fig. 2 ). Because these fine-grained sediments imperfectly confine the water in the underlying coarser sediments and the piezometric surface is usually in the fine-grained sediments in much of the area, ground water in the alluvial deposits in the Tallulah area is considered to be semiconfined.

Ground water generally occurs either under unconfined (watertable) or confined (artesian) conditions. In the alluvial deposits, confinement is usually a matter of degree and varies with the static water level and the rate and period of pumping. The magnitude of the water-level fluctuations in the alluvial aquifer due to atmospheric pressure changes indicates the variation in degree of confinement of the alluvial aquifer. The piezometric surface (an imaginary surface that coincides with the static water level in wells) of a perfectly confined aquifer fluctuates normally in response to barometric, loading, and other pressure changes that may be exerted on the aquifer. In an unconfined aquifer, however, the water table usually is affected only slightly, if at all, by these forces. As shown by figures 3 and 4, the magnitude of the effect of changes in barometric pressure varies with the position of the static water level. When the static water level is in the upper part of the semiconfining layer, the fine-grained material functions as a confining bed, and the water level readily responds to barometric pressure changes (fig. 3 ) ; but, as the water level declines, the effect of pressure changes becomes small. (See fig. 4.) The high ratio of the vertical permeability of the aquifer to that of the semiconfining material allows the release of water instantaneously from storage during an initial period of pumping, and, during this time only, the aquifer functions as an artesian system. After an initial period of pumping, water from the sand in the upper part of the aquifer, especially in the vicinity of the pumped well, drains toward the piezometric pumping surface and becomes a significant part of the total withdrawal. As pumping continues, the effect of this vertical percolation becomes less. However, water from the less permeable semiconfining material overlying the aquifer drains slowly and at a relatively uniform rate throughout the pumping cone of influence. 


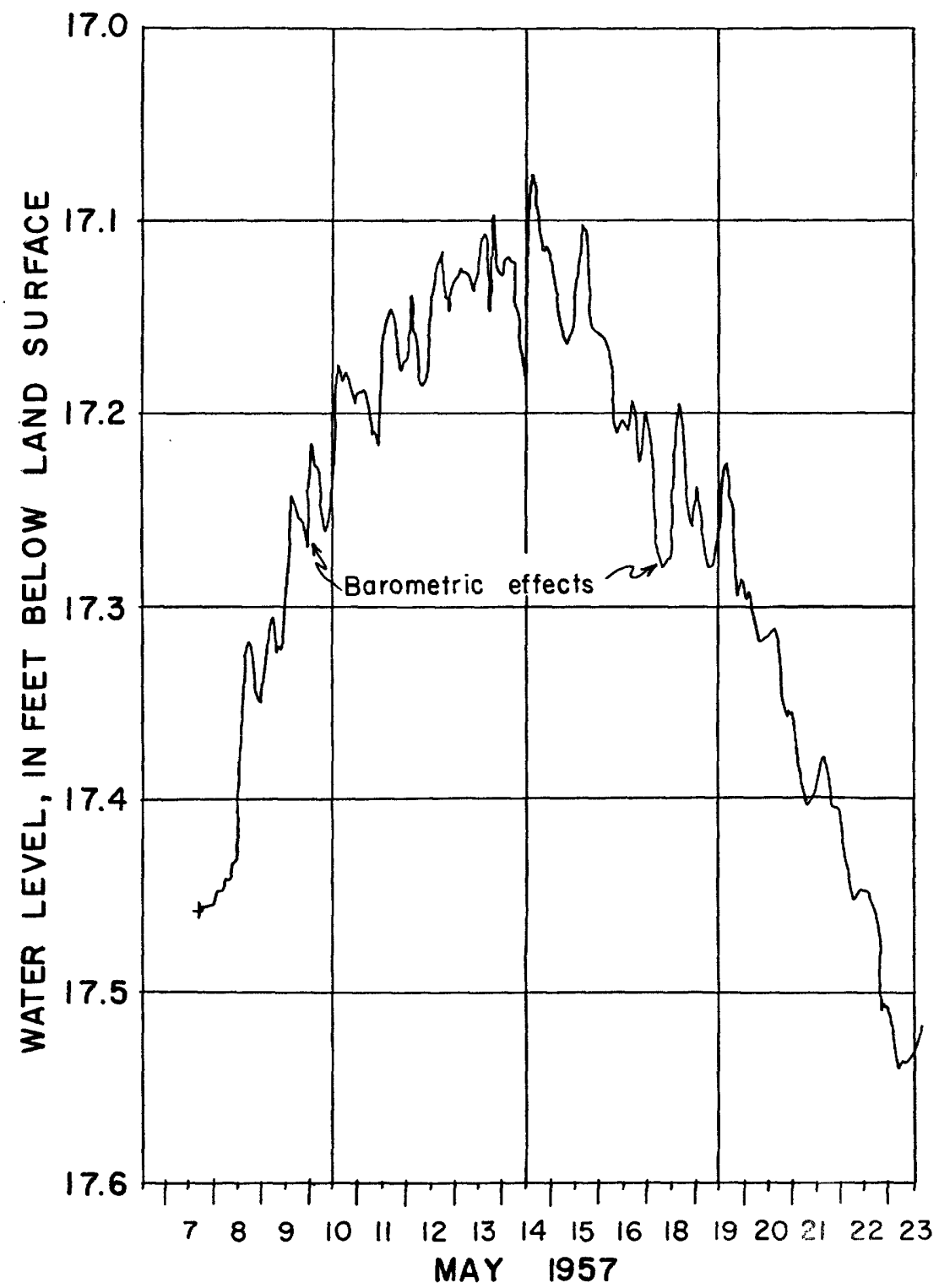

Figurb 3.-Hydrograph showing effect of barometric-pressure changes on water level in observation well Ma-12, May 1957.

\section{PUMPING TESTS}

A pumping test was made in the Tallulah area during the time of year (November-December 1956) when the requirement for ground water was at its minimum. This test was terminated unexpectedly 


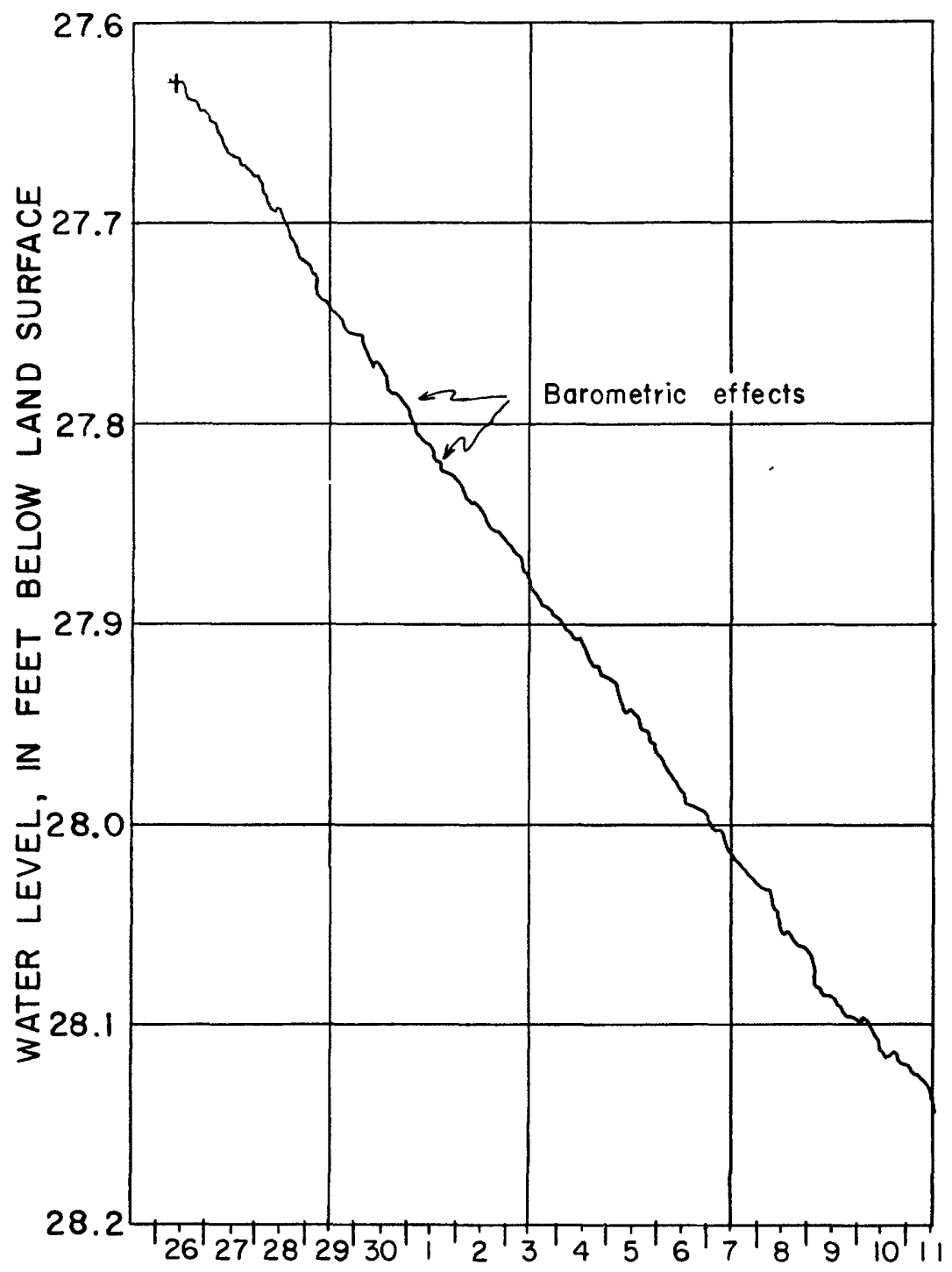

NOVEMBER AND DECEMBER 1956

Figure 4.- - Hydrograph showing effect of barometric-pressure changes on water level in well Ma-12, November-December 1956.

at 1:00 p.m. on December 9,1956 , after about 18,000 minutes of continuous pumping, and therefore recovery measurements were not made. Well Ma-25 was used as the pumped well during the test, and observation wells, their locations dependent upon the availability of space in a cultivated field, were installed at various distances from 


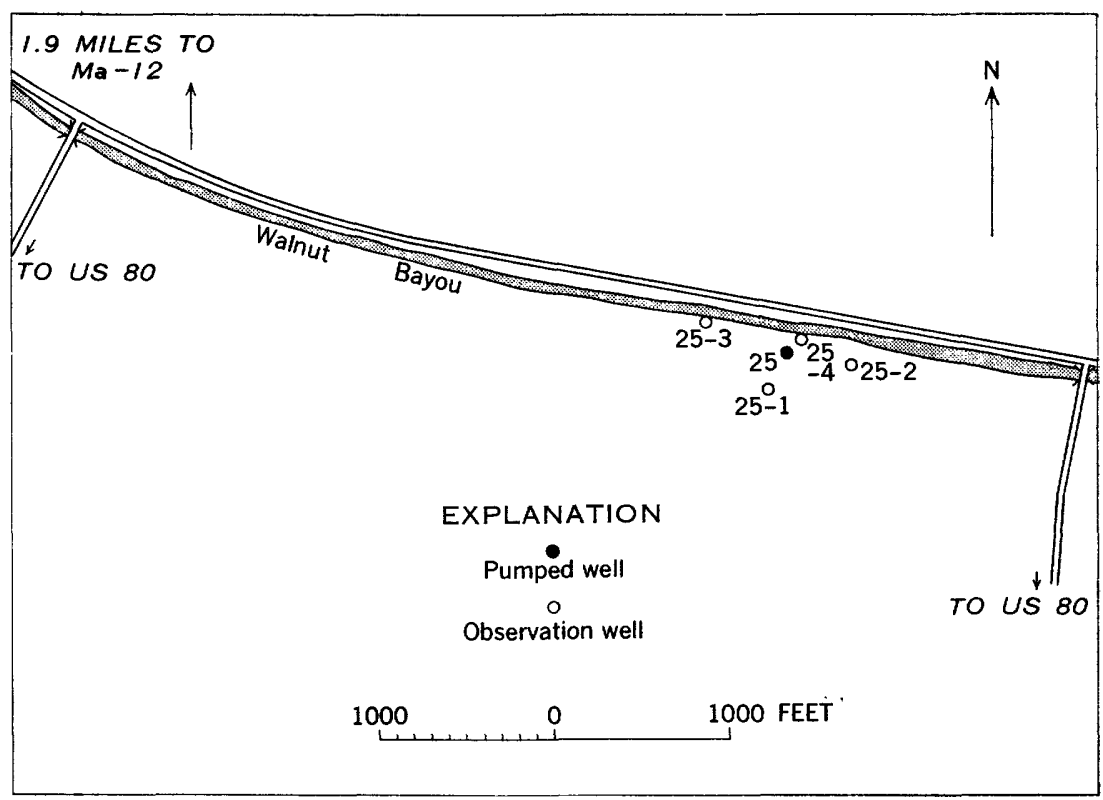

Figure 5.-Location and construction data of pumped and observation wells.

well Ma-25. The construction data for and the location of these wells are given in figure 5. The rate of pumping was measured with a 12- $\times$ 10-inch open-end orifice and regulated with a valve. The well was pumped at an average rate of $3,200 \mathrm{gpm}$. Water levels were measured in the pumped and observation wells with an electrical tape. Changes in barometric pressure were recorded before and during the test periods, and the necessary corrections were made to the observedtrend data. Water-level-trend corrections also were applied.

\begin{tabular}{|c|c|c|c|c|c|c|}
\hline \multirow{2}{*}{ Well } & \multirow{2}{*}{$\begin{array}{l}\text { Distance } \\
\text { from } \\
\text { pumped } \\
\text { well } \\
\text { (feet) }\end{array}$} & \multirow{2}{*}{$\begin{array}{l}\text { Depth to } \\
\text { bottom of } \\
\text { screen } \\
\text { (feet) }\end{array}$} & \multirow{2}{*}{$\begin{array}{l}\text { Diameter } \\
\text { of well } \\
\text { casing } \\
\text { (inches) }\end{array}$} & \multicolumn{2}{|c|}{ Screen } & \multirow{2}{*}{$\begin{array}{c}\text { Altitude of } \\
\text { measuring } \\
\text { point } \\
\text { (feet) }\end{array}$} \\
\hline & & & & $\begin{array}{c}\text { Length } \\
\text { (feet) }\end{array}$ & $\begin{array}{c}\text { Diameter } \\
\text { (mches) }\end{array}$ & \\
\hline $\begin{array}{r}\mathrm{Ma}-25 \\
25-1 \\
25-2 \\
25-3 \\
25-4 \\
12\end{array}$ & $\begin{array}{r}250 \\
375 \\
500 \\
100 \\
11,000\end{array}$ & $\begin{array}{r}166 \\
63 \\
63 \\
63 \\
70 \\
75\end{array}$ & $\begin{array}{l}18 \\
1.25 \\
1.25 \\
1.25 \\
3-1.25 \\
3\end{array}$ & $\begin{array}{c}52.5 \\
3 \\
3 \\
3 \\
3 \\
10\end{array}$ & $\begin{array}{l}14 \\
1.25 \\
1.25 \\
1.25 \\
1.25 \\
3\end{array}$ & $\begin{array}{r}93.53 \\
93.27 \\
94.31 \\
91.53 \\
80.68 \\
\end{array}$ \\
\hline
\end{tabular}

The hydraulic characteristics of the alluvial aquifer in the vicinity of Tallulah were determined by the Theis nonequilibrium method, using only data obtained during the early part of the test. In trial manipulations, logarithmic plots of drawdown versus time were compared with the leaky-aquifer type curve prepared by H. H. Cooper, Jr., of the Geological Survey (written communication, 1958). Even 
though field conditions do not agree with Hantush's (1947, p. 19) assumption "that the head in the aquifer supplying leakage remains uniform," which was used in the derivation of the leaky-aquifer formula the calculated coefficient of transmissibility approximated that determined with the nonequilibrium method. Boulton's equation (1954a, p. 473) for delayed storage was not considered applicable because his assumption "that, above the coarse sand (aquifer), there is a bed of very fine sand and silt in which practically the whole of the depressed water-table is located" was not satisfied. After only a short period of pumping, the water level in the vicinity of the pumped well declined below the base of the fine sand and silt and into the aquifer.

In May 1957 a pumping test was made at well site Ma-25; but, because of a premature start, water levels in the observation wells were not measured until after about 100 minutes. After this time, the quantity of water from drainage significantly affected the water level, and it was not possible to determine the coefficients of transmissibility and storage.

A consistent coefficient of transmissibility of $240,000 \mathrm{gpd}$ per $\mathrm{ft}$ was obtained by using data collected earlier, during the NovemberDecember 1956 test and by using the nonequilibrium method of analysis. The relation of the logarithmic plot of time and drawdown for well Ma-25-2 to the Theis-type curve is shown on figure 6 . On the

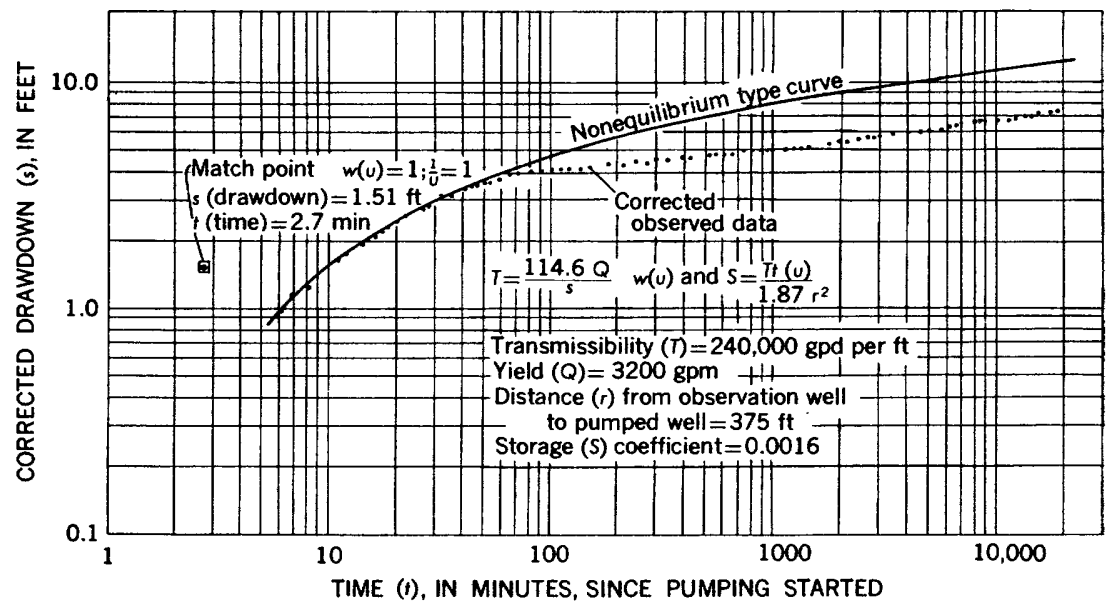

Figuke 6.-Logarithmic time-drawdown plot of water levels in observation well Ma-25-2, November-December 1956.

basis of the aquifer's thickness at the site of well Ma-25 and the coefficient of transmissibility, the average permeability of the sand and gravel is $1,700 \mathrm{gpd}$ per square foot (meinzers), which is slightly higher than the average (1,500 meinzers) permeability of the alluvial de- 
posits in East Carroll and West Carroll Parishes (Poole, 1961, table 13). The average permeability of the alluvial aquifer was reported to be 1,700 meinzers in the Baton Rouge area (Meyer and Turcan, 1955) and 1,900 meinzers in the Grand Prairie region of Arkansas (Engler and others, 1945 , p. 43). Data collected during step-drawdown tests of short duration on wells $\mathrm{Ma}-26$ and -27 were analyzed, and the coefficients of permeability were 1,710 and 1,750 meinzers respectively. Thus, these comparative values indicate that computations made with early data and the nonequilibrium formula do provide a representative permeability value for the alluvial aquifer in the Tallulah area.

The coefficient of storage, which ranged from 0.0016 to 0.0027 and averaged 0.002 , was computed by the Theis nonequilibrium formula from data collected in four wells during the early part of the test. Because the fine-grained sediments confine the water imperfectly, the amount of water released from storage is not constant within the cone of influence, and the calculated storage-coefficient values are considered representative only for the early part of the test. In $1958, \mathrm{~W} . \mathrm{H}$. Walker, formerly with the Geological Survey, analyzed data collected during the pumping tests at Tallulah. He hypothesized (written communication) that a logarithmic plot of time against apparent storage coefficient formed a temporary straight line (fig. 7), which, with con-

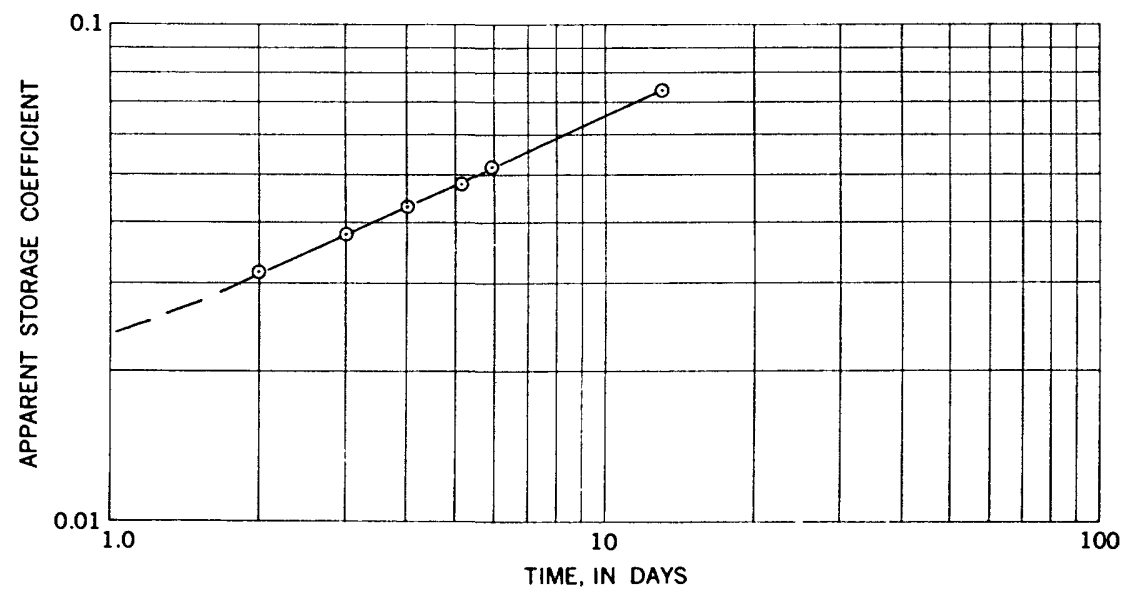

FIGURE 7.-Graph showing logarithmic relation of apparent storage coefficient to time at a distance of 500 feet from the pumped well, November-December 1956.

tinuous pumping, would curve as the apparent storage coefficient approached the effective porosity of the aquifer. The plotted values of apparent storage coefficient on figure 7 were calculated mathematically by substituting into the nonequilibrium formula the corrected 
observed drawdown for a given period of pumping time. This empirical analysis is applicable only for the geologic and hydrologic environments of the Tallulah area. Variance in the quantity of water released from storage or from the overlying fine materials was recognized by R. G. Kazmann (Engler and others, 1945, p. 42, fig. 10).

The semilogarithmic plot (fig. 8) of drawdown in observation well

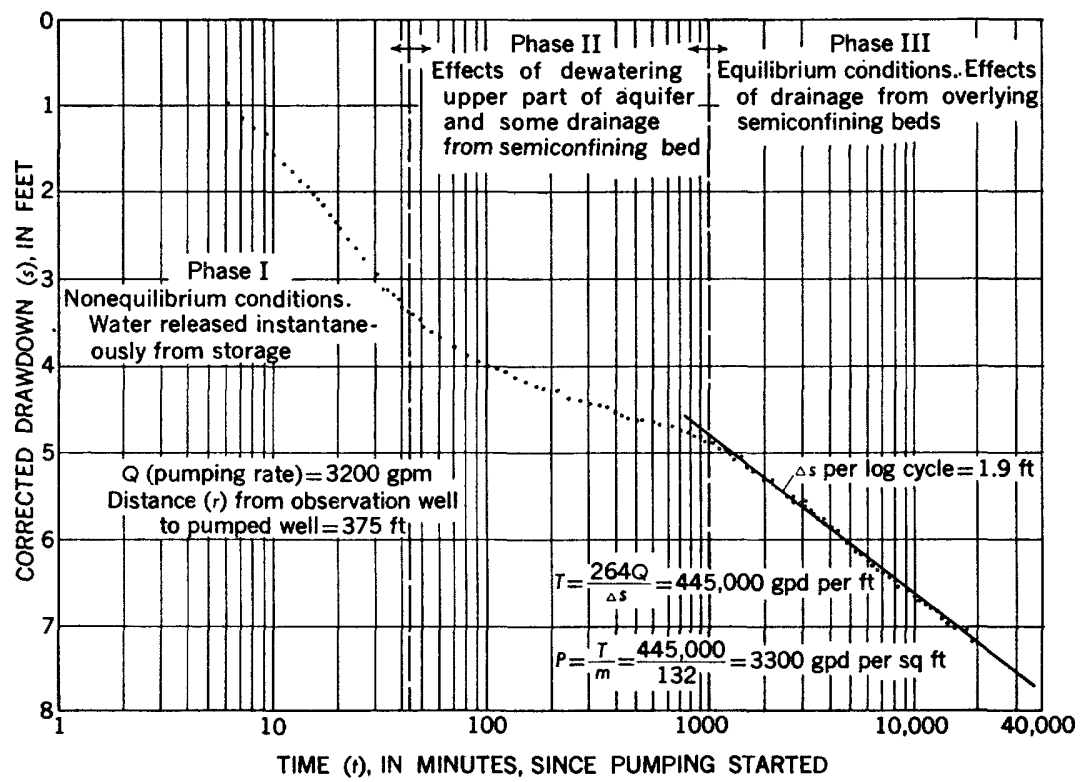

Figurm 8.-Semilogarithmic time-drawdown plot of water levels in observation well Ma-25-2 at test site Ma-25, November-December 1956.

Ma-25-2 against time forms a three-phase curve, which resembles that generally obtained for a water-table aquifer (Walton, 1960b, p. 46). Some of the hydrologic factors, alone or in combination, that could affect the rate of water-level decline are a thickening or thinning of the aquifer; differences in permeability within the cone of influence; drainage from the overlying semiconfining beds; or intersection of the cone of influence with nearby streams, the Mississippi River, or an impervious boundary. The aquifer's thickness (fig. 2) and permeability vary, but the pumping-test data were analyzed as if the aquifer were homogeneous and isotropic. Even though the cone of influence caused by pumping intersects the Mississippi River, the effect of the resultant image well on the cone of influence is not measurable because of the image well's relatively great distance from the test site. Available geohydrologic data indicate that Roundaway and Walnut Bayous have not cut into the aquifer at the sites of the irrigation wells. 
The beds of these streams are composed of silt or clay, which are relatively impermeable; therefore, the slope of the curve for the third phase (or latter part) of the pumping test on well Ma-25-2 (fig. 8) must be attributed to causes other than the connection with the Mississippi River and Walnut Bayou. Analysis of hydrologic and geologic conditions indicates that the rate of water-level decline is affected primarily by water that drains at a relatively uniform rate from the semiconfining beds down through the upper part of the aquifer, to the pumping piezometric surface. The effect of this drainage during the third phase (fig. 8), or the latter part of the test, obviates the use of data collected for calculating the hydraulic characteristics of the semiconfined aquifer at Tallulah by the equilibrium method of analysis (Cooper and Jacob, 1946). For example, the permeability determined by substituting the drawdown over $1 \log$ cycle (fig. 8) and the yield $(3,200 \mathrm{gpm})$ into the equilibrium formula is approximately twice the actual permeability of the alluvial aquifer at Tallulah.

\section{THEORETICAL EFFECTS OF PUMPING}

One of the principal uses of pumping-test results is in calculating the theoretical effect of pumping on water levels, generally by the Theis nonequilibrium method or by an analysis of time-drawdown and distance-drawdown straight-line plots. Except for a short time during the initial period of pumping, anomaloús hydrologic conditions at Tallulah invalidate the use of the nonequilibrium formula for predicting the effect of pumping. However, when the cone of depression reaches equilibrium in form and the rate of drainage from the semiconfining materials is relatively uniform, plots of observed data can be used to approximate the effect of pumping in a pumping well and in a well field.

An indication of well efficiency (in percent) or the effectiveness of well development and construction is estimated by dividing the observed specific capacity of a well by the theoretical specific capacity and multiplying the results by 100 . Specific capacity, which is defined as the yield per unit of drawdown for a given period of pumping, usually is expressed in gallons per minute per foot of drawdown. If the efficiency of a well screened in the shallow alluvial aquifer is less than 100 percent, the difference is due primarily to head loss resulting from turbulent flow around and through the well sereen-commonly called well-entrance loss. The specific capacity of wells in the alluvial valley of northeastern Louisiana and north western Mississippi is given in the section "Development." 


\section{NONEQUILIBRIUM METHOD}

During the initial period of pumping from well Ma-25, conditions conformed to the assumptions used in the development of the Theis nonequilibrium formula. This conformance made it possible to calculate the theoretical specific capacity by substituting into the nonequilibrium formula assumed values for time $(40 \mathrm{~min}$.) and well radius ( 7 in.), and average values of transmissibility ( $240,000 \mathrm{gpd}$ per $\mathrm{ft}$ ) and storage (0.002) computed from early pumping-test data. After 40 minutes of pumping at a rate of $3,200 \mathrm{gpm}$, the calculated specific capacity is $145 \mathrm{gpm}$ per foot of drawdown. Of particular interest is the fact that 88 percent of the total observed drawdown in well Ma-25 occurred during the first 40 minutes of pumping. (See fig. 9.) As shown in figure 9, the observed drawdown in well $\mathrm{Ma}-25$

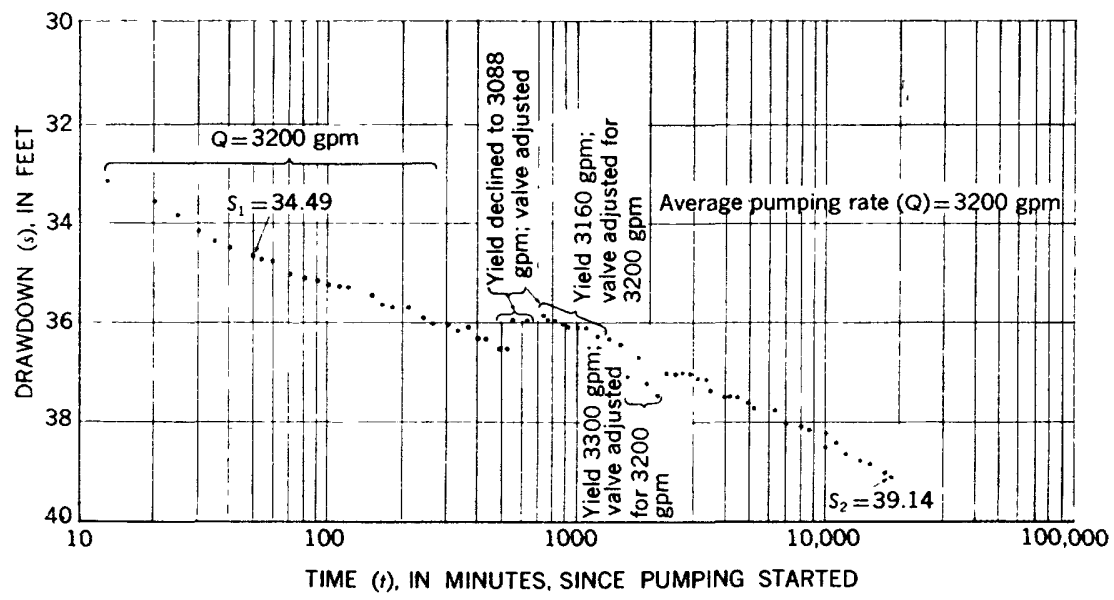

Figorn 9.-Semilogarithmic time-drawdown plot of water levels in pumping well Ma-25, November-December 1956.

at the end of 40 minutes of continuous pumping was 34.49 feet; thus for a yield of $3,200 \mathrm{gpm}$, the observed specific capacity was $92.8 \mathrm{gpm}$ per $\mathrm{ft}$ of drawdown. By dividing this observed specific capacity (92.8 gpm per foot of drawdown) by the theoretical specific capacity (145 gpm per foot of drawdown), the theoretical hydraulic efficiency for well Ma-25 at the end of 40 minutes of pumping is about 64 percent. The divergence of this well's efficiency from 100 percent is caused primarily by turbulent flow around and through the screen, which is the probable result of incomplete well development and increased velocity as the water passes through the screen openings. 
The effect of pumping and the efficiency of the pumped well can be estimated by analyzing the shape of the cone of depression. This can be done by plotting the drawdown $(s)$ in three or more observation wells against the logarithm of distance $(r)$ from the pumped well. Theoretically the observation wells should be in only one direction from the pumping wells; however, provided that the cone of influence is symmetrical, a distance-drawdown plot for wells in different directions and at various distances from the pumped well is satisfactory.

Straight-line semilogarithmic plots of time $(t)$ or radius $(r)$ against drawdown $(s)$ are legitimate only when the cone of depression reaches equilibrium in form-when $u$ is equal to or less than 0.02 (Cooper and Jacob, 1946; Brown, 1953, p. 858). The following general equation for critical drawdown (where $u$ is less than 0.02 ) may be obtained by solving for the constant values and substituting the corresponding $W(u)$ value in the Theis nonequilibrium formula:

$$
s_{c}=\frac{384 \cap}{I^{\prime}}
$$

where $Q$ (the yield) is in gallons per minute and $T$ (the transmissibility) is in gallons per day per foot. On the basis of the coefficient of transmissibility (240,000 gpd per $\mathrm{ft}$ ) for the alluvial aquifer and the average rate of pumping $(3,200 \mathrm{gpm})$, the critical drawdown $\left(s_{c}\right)$ at the end of about 13 days of pumping is calculated to be 5.1 feet.

Even though the slope of the cone of depression is affected by a relatively uniform rate of drainage, which invalidates the use of the equilibrium method for calculating the correct coefficients of transmissibility and storage, the plot of drawdown against the logarithm of distance (fig. 10) forms a straight line and represents the cone of influence for the time and rate of pumping and the prevailing hydrologic conditions. The coefficient of transmissibility computed from the distance-drawdown plot (fig. 1.0) is $268,000 \mathrm{gpd}$ per $\mathrm{ft}$, which is about 10 percent greater than that considered to be correct-240,000 gpd per ft. As the coefficient of transmissibility and the yield from the well are relatively constant, the variation of the theoretical slope of the cone of influence from the actual is caused by a relatively constant rate of vertical percolation, which amounts to about $320 \mathrm{gpm}$ or 10 percent of the average rate of pumping.

The effect of pumping on water levels in wells within a radius of about 700 feet from well $\mathrm{Ma}-25$ can be estimated from figure 10 . Beyond a distance of about 700 feet, the line will curve slightly because 


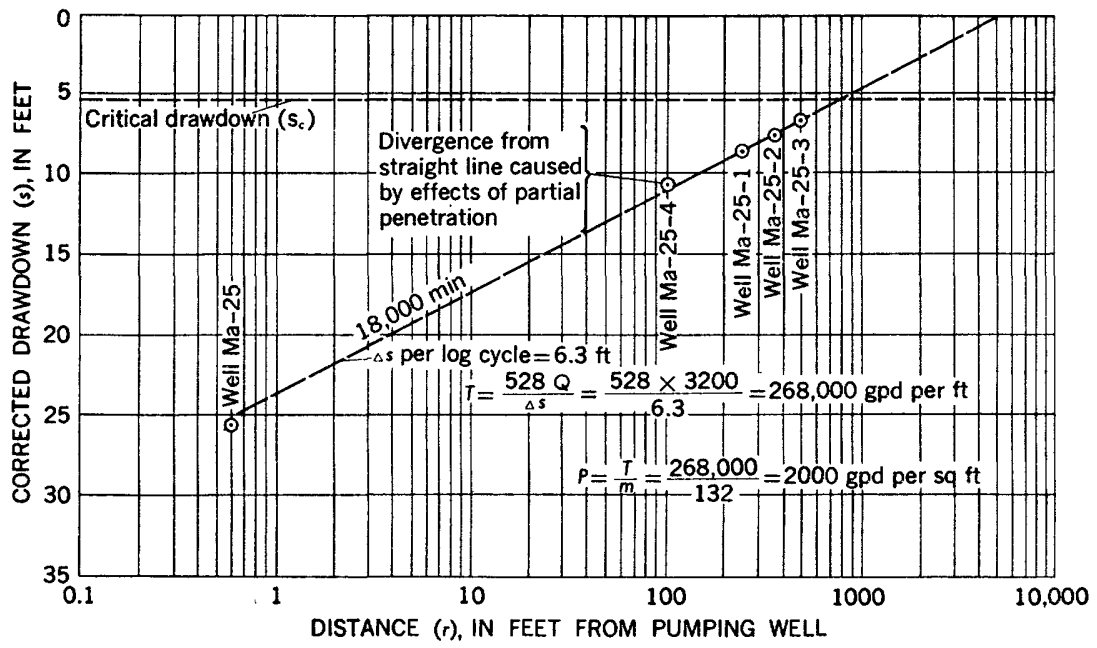

FIGURE 10.-Semilogarithmic distance-drawdown relation for alluvial aquifer after 18,000 minutes of continuous pumping, November-December 1956.

of nonequilibrium conditions, and the effect of pumping can be approximated only. However, the distance-drawdown plot (fig. 10) can be extrapolated to the pumped well to determine the theoretical drawdown, the theoretical specific capacity, and the hydraulic efficiency of the pumped well. As shown on figure 10, the theoretical drawdown in well $\mathrm{Ma}-25$ after 18,000 minutes (approximately 13 days) of continuous pumping is 25.1 feet. Therefore, based upon a yield of 3,200 $\mathrm{gpm}$, the theoretical specific capacity is $128 \mathrm{gpm}$ per foot of drawdown. The observed drawdown in well Ma-25 at the end of 18,000 minutes was 39.1 feet (fig. 9) ; thus, the observed specific gravity well Ma-25 is computed to be $81.8 \mathrm{gpm}$ per foot of drawdown. By dividing the observed specific capacity by the theoretical specific capacity, the hydraulic efficiency of well $\mathrm{Ma}-25$ after 18,000 minutes is about 64 percent, which is the same as that computed for 40 minutes of continuous pumping.

Drawdown data for observation wells at well site Ma-25 obtained during a pumping test made in May 1957 were plotted against the logarithm of distance from the pumped well. The resultant straight line for a pumping period of 5,600 minutes was extrapolated to the pumped well (Ma-25). On the basis of a constant and measured yield of $3,400 \mathrm{gpm}$ and a theoretical drawdown of 26.2 feet, the theoretical specific capacity for the indicated time and yield was $130 \mathrm{gpm}$ per foot of drawdown. The observed drawdown of 41.98 feet in well Ma-25 resulted in an observed specific capacity of $81.5 \mathrm{gpm}$ per foot of drawdown. On the basis of analysis of these data, the efficiency of well 
Ma-25 after pumping 3,400 gpm continuously for 5,600 minutes was about 63 percent. As would be expected, the observed and theoretical specific capacities decrease with increased pumping time; however, the close comparison of the well efficiency for different tests, periods of pumping, and yields indicates the practicability and validity of estimating the effect of pumping by the equilibrium method of analysis.

\section{WATER WELLS}

The primary purpose of a water well is to provide an economical and efficient means of bringing ground water to the surface. Numerous methods exist for constructing wells; the selection of a particular method depends upon the use of the water, the quantity of water required, the depth to the aquifer, the hydrologic and geologic conditions, and the economic factors. In the Mississippi River alluvial valley, small-capacity shallow wells usually are dug, bored, or driven, and large-capacity deeper wells are drilled by the hydraulic-rotary or reverse-circulation methods. The installation of water wells can be divided into four major phases. The first phase is planning, which includes compilation and analyses of available hydrologic and geologic data; to obtain needed or supplemental data, it may be necessary to drill a test hole or holes. The second major phase is the drilling of a hole that will accommodate the specified casing and screen. The third phase is well development. After the casing and the screen are installed, a well should be developed for optimum yield and tested before selecting and installing a permanent pump. The fourth phase is installation of a pump of the required capacity and setting.

\section{TEST DRILLING}

Before drilling and constructing a supply well, especially in an area where hydrologic data are meager, it is common practice to drill a test hole or holes. In addition to determining the exact location of the aquifer containing fresh water, an important objective in test drilling is the collection of representative formation samples. As the depth of the alluvial aquifer at Tallulah was known approximately, the principal purpose of the test drilling was to collect sand samples for analysis. Representative formation samples are required for the proper selection of screen openings, and various sampling methods have been devised to obtain such samples from rotary-drilled holes.

The method used for collecting formation samples during the drilling of the holes near Tallulah was the bucket and decant method. This method generally requires patience, a knowledge of circulation time, a supply of clear water, and a specially designed pipe to channel the cuttings to the point of collection. The cuttings are placed in a 
large vessel and washed slowly with clear water. After the finegrained sediments have been allowed to settle from the drilling fluid, the water may be decanted and a representative sample obtained from the vessel. The sample is then placed in a container, which is marked with the identifying well number and the depth interval.

When drilling with the rotary method in the Mississippi River alluvial valley, where the deposits usually increase in grain size from top to bottom, the mud viscosity should be kept constant to insure uniform and representative samples for the full depth of the test hole. The drilling fluid should be of a viscosity to assure that the coarser materials will be brought to the surface.

During the drilling of test holes a careful record, or a log, was kept of the various strata and their depths, the action of the drilling rig, and the time required to drill each interval. Formation samples were compared with the driller's log and examined in the laboratory to determine the extraneous effects of drilling muds and gel products. Commonly, when samples are improperly washed, the dried drilling mud may be erroneously logged as part of the sample. Sometimes clay, which may slump from the sides of the mud pit and ditch, may contaminate the formation sample, and extreme care was exercised during the collection and the examination of samples to avoid misinterpretations and improper screen selection.

In most areas it is necessary to make an electrical survey after the test hole is drilled to the desired depth. The importance of electrical logging for determining the exact location of fresh-water-bearing sands is discussed in detail by Rose, White, and Livingston (1944), and Jones and Buford (1951). Because of adequate information on the alluvial aquifer in the Tallulah area, it was not necessary to make an electrical survey at the site of each experimental well.

\section{WELL CONSTRUCTION}

\section{DRILLING PROBLEMS}

The reverse-circulation rig used to drill the holes for the experimental irrigation wells, which were a few feet distant from the test holes, was satisfactory for drilling holes of the required diameters (16 and 22 inches) to the specified depths. However, the pit pump did not supply water at a rate adequate to overcome the loss of circulation to the permeable materials. A pump with a capacity of 1,000 gpm was needed and eventually acquired and used to maintain the required constant head. Because of the inadequate water supply, one of the advantages of the reverse-circulation method-that drilling muds are not needed-was lost when drilling muds (aquagel and lime) had to be used during the drilling of the interval to be screened in 
well Ma-26. Even though the aquifer at the site of well Ma-26 is not as thick as it is at wells $\mathrm{Ma}-25$ and -27 , the results of development indicated that the drilling mud had not been flushed completely from the aquifer. The observed specific capacity $(56 \mathrm{gpm}$ per foot of drawdown) should have approximated that (about $90 \mathrm{gpm}$ per foot of drawdown) observed in wells Ma-25 and -27 . The relatively low specific capacity in well Ma-26 also may be attributed to well-entrance loss and to a small decrease in the aquifer's transmissibility. However, incomplete development is considered to be one of the principal causes of the relatively low hydraulic efficiency of well Ma-26.

To allow for proper alinement of the casing and screen, the hole must be drilled vertically. Perfect alinement of the hole and casing was necessary at Tallulah because the hole for the screen was drilled after the casing had been set and cemented. In well Ma-27 the alinement of the hole was slightly off vertical (about $4^{\circ}$ ), and the misalinement was not observed until an attempt was made to set the screen. During installation, the upper 7 feet of the screen was damaged by the bottom of the casing and required repair before use. It was determined that the casing was about $5^{\circ}$ off vertical; therefore, it was necessary to drill the hole for the screen in the same plane as that for the casing. To produce a deflection in the same direction, casing guides were welded onto the drill stem.

Because of the relatively high permeability of the alluvial deposits, the large hole diameter, and the time required to weld and set casing, the hole for the casing should have been drilled below the proposed depth. This would have allowed for slumping or cave-ins and permitted the casing to be set to the desired depth. Because of failure to allow for slumping, the bottom of the casing was set at a depth above that specified.

\section{SCREEN SELECTION}

To reduce the head loss caused by turbulent flow around and through the screen, the open area of the screen should be at a maximum, and flow paths through the screen should be direct and not along a sinuous path. The selection of the openings of the screen, which is called "the heart of the well" by Schreurs (1959, p. 784), should be based upon distribution of grain size in the formation samples. This distribution may be determined by mechanical analyses, using sets of sieves that retain different grain sizes. The cumulative percentage retained by each sieve is determined and is plotted on grain-size graphs. From these graphs it is possible to determine what percentage of the finegrained material will pass through a selected opening. Some screen manufacturers indicate that the screen openings for an irrigation well should be selected to allow the passage of approximately 90 percent 
of the finer grained material. The mechanical analyses of materials collected during test drilling at well sites Ma-25, -26, and -27 indicated that screen openings of 0.080 inch would allow retention of 10 percent of the material. However, on the basis of drilling experience in the area, the water-well contractor decided to use a screen opening of 0.050 inch, which retained more than 10 percent of the finer grained materials.

Some irrigation wells in the Mississippi alluvial valley are gravel packed-the annulus between the well screen and the bore hole is filled with selected coarse sand and gravel to allow for larger screen openings (Harvey, 1956; Poole, 1961). Theoretically, gravel packing decreases the head loss due to turbulent flow in the formation immediately adjacent to the screen. Gravel packing should not be confused with the stabilizing fill method, which is the placement, without special precautions, of ungraded material into the annulus between the screen and hole.

The gravel and coarse-grained sand in the intervals to be screened in the three experimental irrigation wells eliminated the need for gravel packing. The use of natural-packed wells in this area is congenial with suggestions made by Schreurs $(1959$, p. 787$)$ who wrote:

In very fine and uniform sands it may be beneficial to place graded coarse sand or fine gravel around the well screen to form artifically a filter between the screen and the formation sand. This requires a larger casing or bore hole in order to provide an annulus for the placement. Its beneficial effect on the yield of the well is principally because of the increased size of slot openings that can be used in the well screen. Also, a slight increase in yield comes from the larger effective diameter.

The choice to gravel pack should be made on the basis of the conditions in each well. Satisfactory gravel-pack construction requires considerable skill and should be done only by thoroughly qualified men.

\section{DEVELOPMENT}

The completion of a well generally should not end with the placement of the screen. Well development is required to remove detrital materials, concentrate coarse-grained sand and gravel next to the screen, stabilize the aquifer in order to prevent sand pumping, and increase the well's efficiency.

Some of the development methods used in Louisiana are: surging with air or a surge block, cross washing, and overpumping. The experimental irrigation wells at Tallulah were developed by overpumping. When overpumping is used, the test pump should have a greater capacity than the desired well yield (Moss, 1958, p. 786). Sayre and Livingston (1945) suggested that the permanent pump capacity be not 
more than two-thirds the developed capacity. Even though the development of the experimental wells was considered to be satisfactory, they were not developed to optimum yield because of the relatively small capacity (about $3,600 \mathrm{gpm}$ ) of the test pump. The desired yield was $3,000 \mathrm{gpm}$; therefore, the wells should have been developed to a capacity of about $4,500 \mathrm{gpm}$.

Specific capacity generally is an indication of the productivity of a well and may indicate the success of well development. Before development, a 15- or 30-minute specific-capacity test was made in each experimental well. After varying periods (8 to $10 \mathrm{hrs}$ ) of daily development, the pump was turned off until the following morning. A specific-capacity test was then made to determine the effects of previous development. As development was continued, the fine material in the immediate vicinity of the well screen was removed and the specific capacity increased. The specific capacity of well Ma-25 on August 5,1956 , was $88 \mathrm{gpm}$ per foot of drawdown at a yield of $3,250 \mathrm{gpm}$. On the morning of August 6, after 1 day of continuous development, the specific capacity had increased to $93.5 \mathrm{gpm}$ per foot of drawdown with a yield of $3,350 \mathrm{gpm}$. The specific capacity for well Ma-26 increased daily from a low of about $45 \mathrm{gpm}$ per foot of drawdown with a yield of $1,475 \mathrm{gpm}$ on July 19,1956 , to $52 \mathrm{gpm}$ per foot of drawdown with a yield of $2,700 \mathrm{gpm}$ on July 31,1956 . The specific capacity in well Ma-27 after only 1 day of development increased from $100 \mathrm{gpm}$ per foot of drawdown with a yield of $3,590 \mathrm{gpm}$ to $103.5 \mathrm{gpm}$ per foot of drawdown with a yield of $3,560 \mathrm{gpm}$.

Step-drawdown tests were made in each experimental well to determine if the critical discharge had been reached. Critical discharge is reached when the specific capacity decreases rather abruptly with increased yield. Because of possible errors in the measurements of yield and water level, a small variation from a straight line might be expected when specific capacity is plotted against increased yield. Plots of specific capacity against increased yield for wells $\mathrm{Ma}-25$, -26 , and -27 indicate that the critical discharge had not been reached at their maximum yield.

The quality of the water-high total iron and hardness contentin the alluvial deposits combined with excessive head losses at the face of the screen may cause screen incrustation. Over a period of time, the incrustation tends to reduce the specific capacity of a well. Even though the experimental wells at Tallulah wore not developed to their maximum efficiency, the specific capacity of wells $\mathrm{Ma}-25$, -26 , and -27 has not decreased over a period of about 4 years (1956-60). (See table 1.) 
TABLe 1.-Measured operating yield and specific capacity of experimental irrigation wells in the Tallulah area, Madison Parish, La.

\begin{tabular}{|c|c|c|c|c|c|}
\hline USGS well & Date of tests & $\begin{array}{l}\text { Duration of } \\
\text { tests (min.) }\end{array}$ & $\begin{array}{l}\text { Static water } \\
\text { leve. (feet) }\end{array}$ & Yield (gpm) & $\begin{array}{l}\text { Specific } \\
\text { capacity } \\
\text { (gpm per } \\
\text { foot) }\end{array}$ \\
\hline $\begin{array}{l}\mathrm{Ma}-25 \\
26 \ldots \\
27\end{array}$ & $\begin{array}{l}\text { July } 1960 \\
\text { July } 1960 \\
\text { July } 1960\end{array}$ & $\begin{array}{r}110 \\
80 \\
37 \\
\end{array}$ & $\begin{array}{l}20.45 \\
11.40 \\
10.45 \\
\end{array}$ & $\begin{array}{l}4,100 \\
3,300 \\
3,900 \\
\end{array}$ & $\begin{array}{l}89.3 \\
56.4 \\
99.6 \\
\end{array}$ \\
\hline $\begin{array}{l}\mathrm{Ma}-25 \ldots \\
26 \\
27\end{array}$ & $\begin{array}{l}\text { December 1956 } \\
\text { October } 1956 \ldots \\
\text { August } 1956\end{array}$ & $\begin{array}{r}110 \\
80 \\
38\end{array}$ & $\begin{array}{l}26.74 \\
17.00 \\
17.70\end{array}$ & $\begin{array}{l}3,200 \\
3,400 \\
3,500\end{array}$ & $\begin{array}{r}90.8 \\
56.6 \\
102.0\end{array}$ \\
\hline
\end{tabular}

\section{SPECIFIC CAPACITY}

Even though the specific capacity of wells $\mathrm{Ma}-25$ and -27 is below the theoretical specific capacity, the yield and observed specific capacity are above the average measured and reported for wells in the alluvial valley in northeastern Louisiana and northwestern Mississippi. The data contained in table 2 were compiled from data presented by Poole (1961) and Harvey (1956). The specific capacity of the irrigation wells listed in table 2 ranges from 19 to $185 \mathrm{gpm}$ per foot of drawdown and averages 66 . The average yield for the 48 representative irrigation wells listed in table 2 is $1,900 \mathrm{gpm}$.

\section{PUMTS}

Proper pump installation involves a knowledge of the type of power, required pump capacity, casing diameter needed to accommodate the pump, and the required pump setting. Generally the type of power to be used is decided on the basis of availability and cost. For planning, the required pump capacity, size of casing, and pump setting are estimated from water requirement and hydrologic and geologic data. However, the pump and motor should not be selected until the well has been developed satisfactorily and the detailed hydrologic data necessary for pump and motor design have been obtained.

Preliminary information indicated that a yield of $3,000 \mathrm{gpm}$ per well was obtainable. Therefore a 16 -inch-diameter pump was required. On the basis of the expected dynamic head and yield, it was estimated that a 125-hp motor would be required. Because of the limited availability of large pumps and motors at the time the wells were installed, the final selection of the pump and motors was made on the basis of the preliminary data and not on the basis of final data. A 16-inch 1-stage deep-well turbine pump with a rated capacity of $3,200 \mathrm{gpm}$ was installed on each well, and each was powered by a 125-hp 60-cycle 1,770-rpm 3-phase 440-volt electrical motor. If the final selection had been delayed, wells $\mathrm{Ma}-25$ and -27 probably would 
TABLE 2.-Specific capacity of irrigation wells in northeastern Louisiana and northwestern Mississippi

\begin{tabular}{|c|c|c|c|c|c|c|c|c|c|}
\hline $\begin{array}{l}\text { Parish or } \\
\text { County }\end{array}$ & Well & $\begin{array}{l}\text { Diam- } \\
\text { eter } \\
\text { (inches) }\end{array}$ & $\begin{array}{l}\text { Yield } \\
(\mathrm{gpm})\end{array}$ & $\begin{array}{c}\text { Specific } \\
\text { capacity } \\
\text { (gpm } \\
\text { per ft) }\end{array}$ & $\begin{array}{l}\text { Parish or } \\
\text { County }\end{array}$ & Well & $\begin{array}{c}\text { Diam- } \\
\text { eter } \\
\text { (inches) }\end{array}$ & $\begin{array}{l}\text { Yield } \\
\text { (gpm) }\end{array}$ & $\begin{array}{l}\text { Specific } \\
\text { capacity } \\
\text { (gpm } \\
\text { per ft) }\end{array}$ \\
\hline \multicolumn{10}{|c|}{ Northeastern Louisiana } \\
\hline East Carroll.... & $\begin{array}{r}\text { EC-19 } \\
33 \\
39 \\
41 \\
42 \\
44 \\
52 \\
60 \\
61 \\
62 \\
64 \\
65 \\
72 \\
80\end{array}$ & $\begin{array}{r}14 \\
16 \\
16 \\
12 \\
12 \\
18 \\
12 \\
12 \\
8 \\
12 \\
12 \\
16 \\
12 \\
12\end{array}$ & $\begin{array}{r}1,235 \\
1,725 \\
1,470 \\
1,475 \\
1,880 \\
1,900 \\
2,000 \\
800 \\
400 \\
2,300 \\
2,450 \\
2,100 \\
700 \\
1,100\end{array}$ & $\begin{array}{r}39 \\
64 \\
49 \\
42 \\
37 \\
47 \\
80 \\
40 \\
20 \\
92 \\
100 \\
70 \\
25 \\
48\end{array}$ & East Carroll.... & $\begin{array}{r}\text { EC-86 } \\
92 \\
94 \\
95 \\
98 \\
99 \\
100 \\
109 \\
110 \\
\text { W C-19 } \\
20 \\
21 \\
32\end{array}$ & $\begin{array}{r}16 \\
12 \\
16 \\
16 \\
16 \\
12 \\
16 \\
10 \\
12 \\
8 \\
12 \\
16 \\
8\end{array}$ & $\begin{array}{r}2,200 \\
810 \\
2,000 \\
490 \\
1,000 \\
1,800 \\
2,300 \\
2,800 \\
2,500 \\
460 \\
600 \\
2,550 \\
1,600\end{array}$ & $\begin{array}{l}60 \\
45 \\
60 \\
29 \\
36 \\
40 \\
50 \\
70 \\
71 \\
77 \\
19 \\
75 \\
40\end{array}$ \\
\hline \multicolumn{10}{|c|}{ Northwestern Mississippi } \\
\hline $\begin{array}{l}\text { Coahoma...... } \\
\text { Humphrey..... }\end{array}$ & $\begin{array}{r}D-4 \\
F-20 \\
G-3 \\
L-3 \\
15 \\
16 \\
D-1 \\
2 \\
O-9 \\
F-5 \\
J-1\end{array}$ & $\begin{array}{l}16 \\
16 \\
12 \\
16 \\
16 \\
16 \\
18 \\
12 \\
14 \\
12 \\
10\end{array}$ & $\begin{array}{l}3,000 \\
2,390 \\
2,750 \\
2,490 \\
2,330 \\
2,050 \\
2,210 \\
2,750 \\
5,000 \\
1,850 \\
1,100\end{array}$ & $\begin{array}{r}89 \\
75 \\
101 \\
78 \\
63 \\
52 \\
58 \\
80 \\
185 \\
62 \\
73\end{array}$ & $\begin{array}{l}\text { Humphrey..... } \\
\text { Leflore........ } \\
\text { Sunflower..... } \\
\text { Tallahatrhie... } \\
\text { Tunica....... } \\
\text { Washington .... }\end{array}$ & $\begin{array}{r}F-2 \\
\mathrm{C}-2 \\
\mathrm{E}-4 \\
13 \\
\mathrm{C}-2 \\
\mathrm{H}-1 \\
\mathrm{R}-4 \\
\mathrm{C}-3 \\
\mathrm{D}-2 \\
\mathrm{~L}-9\end{array}$ & \begin{tabular}{r|}
6 \\
12 \\
10 \\
10 \\
16 \\
18 \\
12 \\
12 \\
16 \\
16
\end{tabular} & $\begin{array}{r}500 \\
3,150 \\
2,210 \\
2,090 \\
1,880 \\
2,390 \\
1,160 \\
3,200 \\
2,650 \\
3,030\end{array}$ & $\begin{array}{r}100 \\
112 \\
74 \\
95 \\
47 \\
77 \\
58 \\
82 \\
72 \\
101\end{array}$ \\
\hline
\end{tabular}

have been equipped with a pump with a rated capacity of $4,000-4,500$ gpm and a 175-hp motor.

\section{POTENTIAL SUPPLY SUMMARIZED}

The largest yield observed in the Tallulah area, about 4,000 gpm, is from well Ma-25. However, this yield is not considered the maximum that can be developed from a single well in the area. The potential yield of wells can be estimated on the basis of the hydrologic properties of the alluvial aquifer. The theoretical specific capacity of a properly developed and constructed well with an efficiency of 100 percent has been shown to be about $130 \mathrm{gpm}$ per foot of drawdown after pumping 13 days. Therefore, the yield of such an ideal well in the alluvial aquifer would be slightly more than $7,000 \mathrm{gpm}$, if the drawdown in the well was 55 feet. As the static water level is approximately 20 feet below the land surface in the area, the water level in the pumped well at the above pumping time and rate would be about 75 feet below the land surface.

A group of 10 wells of this type, spaced so as to not interfere with each other, would yield about $100 \mathrm{mgd}$ (million gallons a day) or 155 cfs to supply irrigation requirements. Based on the profile of the 
observed cone of depression at the end of about 13 days of pumping (fig. 10), the drawdown at a distance of 10,000 feet from a pumped well would be negligible. In addition, as the cone of influence expands in response to longer pumping periods, more and more water will be diverted from the Mississippi River. This diversion will result in a decrease in the rate of water-level decline, and it is estimated that 10 wells spaced along the Walnut-Roundaway Bayou system at 3 -mile intervals would supply $100 \mathrm{mgd}$ without excessive mutual interference. In fact, at the end of a 13-day pumping period all the water now being discharged from the aquifer into the Mississippi River adjacent to the developed area would not be diverted toward the pumping wells. To salvage the natural discharge of water to the river and induce river water to recharge the aquifer, wells would have to be near the river and pumped at a high rate.

The large potential yield of the alluvial aquifer is assured by the proximity of the Mississippi River, which functions as a potential source of recharge. For example, Poole (1961) shows that in East and West Carroll Parishes, low stages of the Mississippi River cause greater water-level declines in the aquifer than those caused by the discharge from all the irrigation wells.

Disregarding quality-of-water requirements, the principal problem in obtaining a large supply of ground water in the Tallulah area is the construction and development of wells with a diameter and efficiency capable of yielding the quantity of water the aquifer will transmit.

\section{SELECTED REFERENCES}

Boulton, N. S., 1954a, Unsteady radial flow to a pumped well allowing for delayed yield from storage: Internat. Assoc. Sci. Hydrology, Assemblée Gén. Rome, tome 2.

1945b, The drawdown of the water-table under non-steady conditions near a pumped well in an unconfined aquifier : Inst. Civil Engineers Proc., v. 3, pt. 3, p. 564-597.

Brown, R. H., 1953, Selected procedures for analyzing aquifer test data: Am. Water Works Assoc. Jour., v. 45, no. 8, p. 844-866.

Cooper, H. H., and Jacob, C. E., 1946, A generalized graphical method of evaluating formation constants and summarizing well-field history : Am. Geophys. Union, v. 27, no. 4, p. 526-534.

Engler, Kyle, Thompson, D. G., and Kazmann, R. G., 1945, Ground water supplies for rice irrigation in the Grand Prairie Region, Arkansas: Arkansas Univ. Agr. Expt. Sta. Bull. 457, 56 p.

Fenneman, N. M., 1938, Physiography of eastern United States: New York and London, McGraw-Hill Book Co., 714 p.

Fisk, H. N., 1944, Geological investigation of the alluvial valley of the lower Mississippi River: U.S. Army Corps of Engineers, Mississippi River Comm., $78 \mathrm{p}$. 
Hantush, M. S., 1957, Preliminary quantitative study of the Roswell groundwater reservoir, New Mexico: New Mexico Inst. Mining and Technology, Socorro, $118 \mathrm{p}$.

Harvey, E. J., 1956, Records of wells in the alluvium in northwestern Mississippi: Mississippi Geol. Survey and Mississippi Board of Water Commissioners, Bull. 56-1, $130 \mathrm{p}$.

Hirsch, A. A., 1945, Manual for water plant operators: Brooklyn, Chemical Publishing Co., 386 p.

Johnston, C. N., 1951, Irrigation wells and well drilling: California Agr. Expt. Sta. Circ. 404, 32 p.

Jones, P. H., and Buford, T. B., 1951, Electric logging applied to ground-water exploration: Geophysics, v. 16, no. 1, p. 115-139.

Kristal, F. A., and Annett, F. A., 1953, Pumps : New York, McGraw-Hill, 373 p.

Low, J. W., 1951, Examination of well cuttings: Colorado School of Mines Quarterly, v. 46, no. 4, 48 p.

McEllheney, W. A., 1960, Application of rotary drilling to water wells: Am. Water Works Assoc. Jour., v. 52, no. 3, p. 351-355.

Meyer, R. R., and Turcan, A. N., Jr., 1955, Geology and ground-water resources of the Baton Rouge area, Louisiana: U.S. Geol. Survey Water-Supply Paper 1296, table 4.

Mogg, J. L., 1959, Effects of aquifer turbulence on well drawdown: Am. Soc. Civil Eng. Proc., v. 85, no. Hy 11, p. 99-112.

Moss, Roscoe, Jr., 1958, Water well construction in formations characteristic of the southwest: Am. Water Works Assoc. Jour., v. 50, no. 6, p. 777-788.

Mylander, H. A., 1953, Oil field techniques for water well drilling: Am. Water Works Assoc. Jour., v. 45, no. 7, p. 764-772.

Poole, J. L., 1961, Ground-water resources of East Carroll and West Carroll Parishes, Louisiana : Louisiana Dept. Public Works, 174 p.

Rorabaugh, A. M., 1953, Graphical and theoretical analysis of step-drawdown test of artesian well : Am. Soc. Civil Hng. Proc., v. 79, Separate 362, 23 p.

Rose, N. A., White, W. N., and Livingston, Penn, 1944, Exploratory water-well drilling in the Houston district, Texas: U.S. Geol. Survey Water-Supply Paper 889-D.

Sayre, A. N., and Livingston, Penn, 1945, Ground-water resources of the El Paso area, Texas: U.S. Geol. Survey Water-Supply Paper 919, 190 p.

Schreurs, R. L., 1959, Elements of well construction: Am. Water Well Assoc. Jour., v. 51, no. 6, p. 781-789.

U.S. Army Corps of Engineers, Mississippi River Comm., 1950, Mississippi River Hydrographic Survey, 1948-1949, Mouth of Arkansas River to Vicksburg, Miss.

1956, Investigation of underseepage Mississippi River levees: Waterways Expt. Sta. Tech. Memo. 3-430.

- 1958, Stages and discharges of the Mississippi River and its outlets and tributaries, 1958.

Walton, W. C., 1960a, Leaky artesian aquifer conditions in Illinois: Illinois Geol. Survey Rept. Inv. 39, 27 p.

$1960 \mathrm{~b}$, Application and limitation of methods used to analyze pumping test data, pt. 2 : Natl. Water Well Jour., v. 14, no. 3, p. 20-52. 


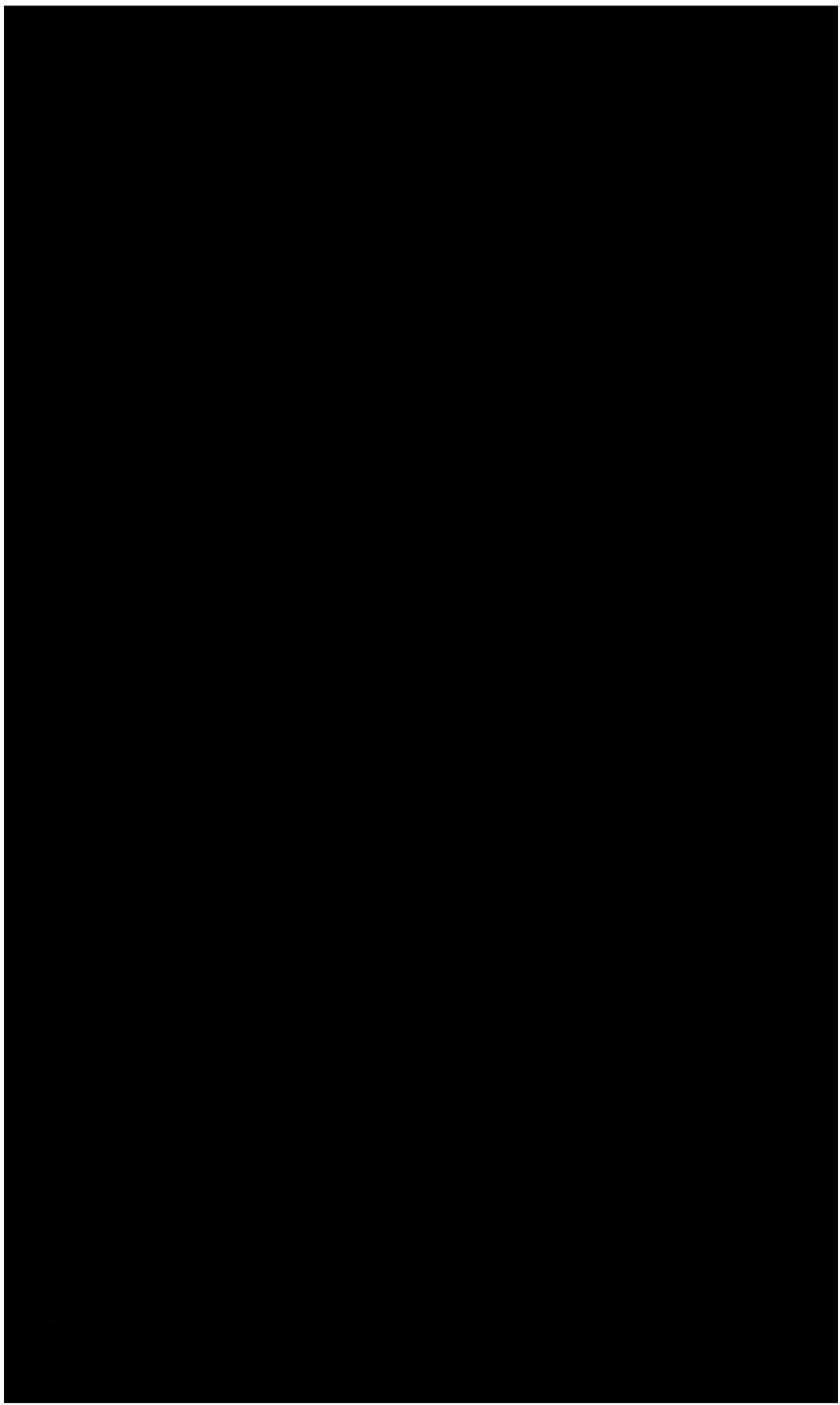




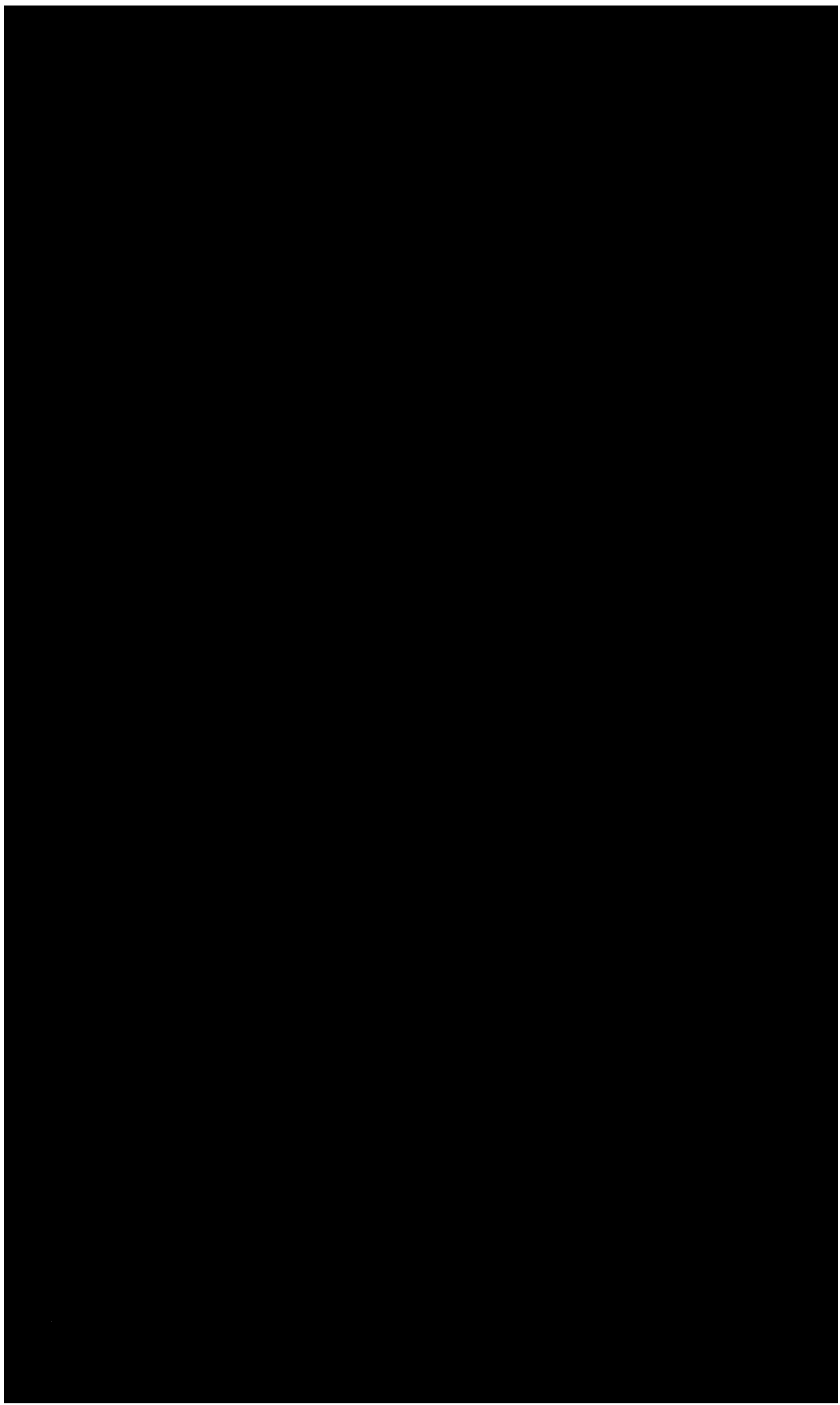

